\title{
Internal factors that affect SMEs to export: A case study of Footwear Cluster
}

\author{
Wawan Dhewanto, Sri Herliana*, Donald Crestofel Lantu, Nur Lawiyah \\ Institut Teknologi Bandung, School of Business and Management, Bandung, Indonesia
}

\begin{abstract}
Cibaduyut is one of the footwear clusters that have a high potential in terms of export. The development of globalization creates new pressures and opportunities in competition for SMEs nationally and internationally; the internal factors, playing an important role for SMEs to export. The purpose of this study is to determine what internal factors affect the decision of SMEs in the cluster to export, how, and what the future recommendations to develop export activities in Cibaduyut cluster. The research method used in this research is by using a quantitative method to 10 respondents that have export experience by using frequency data approach. From the frequency data studied, 10 internal factors that include, strong business capital, skilled workforce, good product made, strategic location, intensive marketing, adequate machine tools, adequate warehouse, attractive packaging, foreign language skills, and availability of raw materials, studied to 10 respondents by using the data frequency approach of the development hypothesis, indicates that only the language factor is rejected in the hypothesis testing.
\end{abstract}

\section{Introduction}

The effect of globalization on trade is to open a country's economic gate for export. SMEs have a role as a strengthening of a country's economy. From the SME sector created positive business activities, especially in making jobs and developing other busi-ness potentials such as export activities. Export ac-tivities for SMEs are the gateway to enter the inter-national market. However, in practice not all SMEs dare to export, which of course is based on internal factors and external factors. Cibaduyut is one of the famous footwear clusters in Indonesia. Although it has stood since very long, but the SMEs there still do not have enough courage to do export. They have a very high potential for export, including having good quality products, competitive prices, and having skilled craftsmen. Although they have not dared to export directly, but some SMEs do indirect exports, through overseas customers who come and buy Cibaduyut products directly and through brokers. What are the factors affecting SMEs to export and enter the international market in Cibaduyut cluster. In this study, researchers focused on examining internal factors affecting SMEs in Cibaduyut to conduct and participate in international markets. This research uses quantitative research approach measured from the frequency of respondents to internal factors that researchers mention based on literature support. From this research will be known what are the factors that influence SMEs in Cibaduyut for export, and how the recommendations for the future.

\section{Hypothesis Development:}

H1: Strong business capital [1], has a positive impact on export activities in Cibaduyut.

H2: Skilled workforce [2], has a positive impact on export activities in Cibaduyut.

H3: Good product made [1,3], has a positive impact on export ac-tivities in Cibaduyut.

H4: Strategic location [4], has a positive impact on export activ-ities in Cibaduyut.

H5: Intensive marketing [5], has a positive impact on export ac-tivities in Cibaduyut.

H6: Adequate machine tools [1], has a positive impact on export activities in Cibaduyut.

H7: Adequate warehouse [1], has a positive impact on export activities in Cibaduyut.

H8: Attractive packaging [1,3], has a positive impact on export ac-tivities in Cibaduyut.

H9: Foreign language skills [6], has a positive impact on export ac-tivities in Cibaduyut.

H10: Experience of export [1], has a positive impact on export activities in Cibaduyut.

\footnotetext{
Corresponding author: sri.herliana@s,sm-itb.ac.id
} 


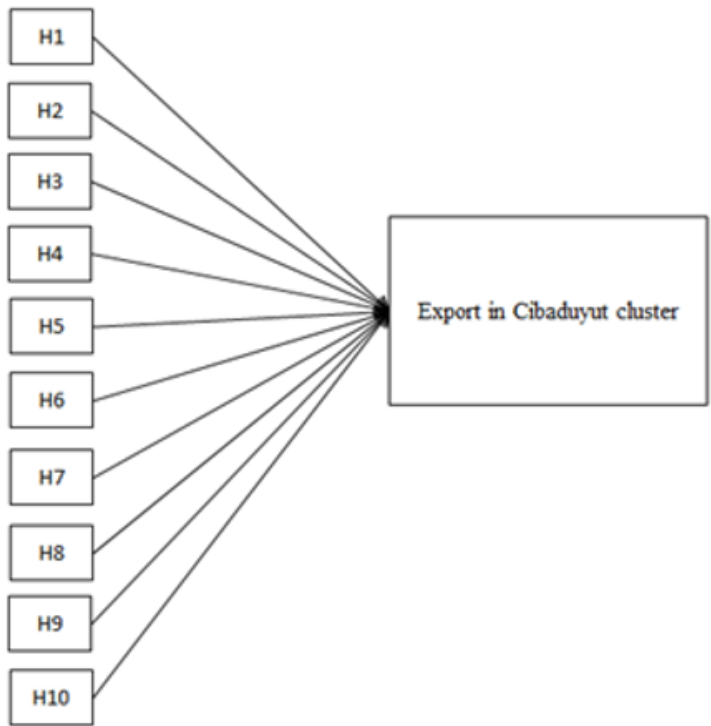

Fig 1. Hypothesis Development

\section{Literature Review}

\subsection{SMEs for export}

The development of globalization creates new pressures and opportunities in competition for SMEs nationally and internationally. Opportunities that could be exploited by SMEs in the development of globalization, such as increased productivity and im-proved markets [7]. International expansion has opened the way for SMEs to grow by expanding their customer base to increase profitabil-ity and growth [8]. The willingness, ability, and motivation of the owners / managers in making decisions, often influence the successful ap-plication of international entrepreneurial ideas [9]. However, in practice, the growing international development has made it difficult for small sectors to develop, as they have to face obstacles in order to survive and com-pete in international markets [10]. It makes, the contribution of SMEs in international is still very low compared with their contribution in the country. In fact, many government programs to sup-port SMEs in order to enter the international market [8]. Therefore, SMEs now, should be able to develop competitive ability, innovation, and relationships in order to participate actively in the in-ternational market [10].

\subsection{Internal factor for export}

Internal factors, playing an important role for SMEs to export, these internal factors include the quality of the products offered, the resources owned, the scale of the company, the management of the enterprise, and the experience of exports [1]. The researcher assumes that internal factors for export are factors related to the condition of the company, such as location, marketing, innovation, skilled labor, and language skills, in addition to the factors mentioned earlier. The company's location factor for SMEs in general has an influence on the company's ability to export, although it is not felt directly [4]. The company's skilled labor is one of the decisive factors for the company to export. Skilled labor is closely related to higher work productivity [2]. The company's commitment to export orientation with innovation has a role to the success of exports [3]. Most of the success of exports comes from the ability of firms to implement marketing strategies effectively [5]. Foreign language skills and abilities are a key factor in the international market in customer relationships. Communication problems that occur in the international market, because they do not understand each other English language used, or use a bad translation [6]

\section{Methodology}

The research method used in this research is by using quantitative method to 10 respondents that has export experience, to know what internal factors that influences SMEs to conduct and enter into international market or export. The quantitative method uses a frequency approach, which is judged by how many respondents score each variable. Score value using a linkert scale approach that is from 1-5. This study is also supported by literature data from journals, articles, books, electronic newspapers, proceedings, and other sources that support the literature search about export factors and around the cluster Cibaduyut. The purpose of this study is to determine what internal factors affect the decision of SMEs in the cluster Cibaduyut to export and how and what the future recommendations to develop export activities in clusters Cibaduyut.

\section{Analysis and Discussion}

\subsection{Respodent's profile}

Profile of respondents in this study to 10 SMEs is 6 respondent's business owners and 4 employees in the field of marketing. Their educational background was 5 respondents who received high school education, 2 respondents received junior high school education, 1 respondent received diploma education, and 2 respondents received bachelor degree. The SMEs age in this study are the oldest was 32 years old and the youngest was 4 years old. The majority of them can export from foreign buyers who come directly to Cibaduyut to buy Cibaduyut products that will be brought to their country and through brokers. The majority of them do not apply price differences between domestic and overseas buyers. There are many 
competitors and Cibaduyut products are already known as a product with an affordable price. Although this cluster has been established for a long time, but few SMEs have export experience.

\subsection{Hypothesis testing by internal factor frequency data}

The testing hypothesis based on the frequency data on internal export factor in Cibaduyut cluster can be seen below;

Table 1. Internal factor frequency data affecting export activities in Cibaduyut

\begin{tabular}{|c|c|c|c|c|c|c|c|}
\hline \multirow{2}{*}{$\begin{array}{l}\text { Internal } \\
\text { Variables }\end{array}$} & \multirow{2}{*}{$\begin{array}{l}\text { Hypothesi } \\
\text { s }\end{array}$} & \multicolumn{5}{|c|}{\begin{tabular}{|l} 
Data \\
Frequency
\end{tabular}} & \multirow[t]{2}{*}{ Tota } \\
\hline & & 1 & 2 & 3 & 4 & 5 & \\
\hline Strong business capital & H1 & & & 1 & 1 & 8 & 10 \\
\hline Skilled workforce & $\mathrm{H} 2$ & 2 & & & 2 & 6 & 10 \\
\hline Good product made & H3 & & & 4 & 1 & 5 & 10 \\
\hline Strategic location & $\mathrm{H} 4$ & 1 & & 5 & & 4 & 10 \\
\hline Intensive marketing & H5 & 1 & 1 & 1 & & 7 & 10 \\
\hline Adequate machine tools & H6 & 3 & & 1 & 2 & 4 & 10 \\
\hline Adequate warehouse & $\mathrm{H} 7$ & 3 & 1 & & & 6 & 10 \\
\hline Attractive packaging & $\mathrm{H} 8$ & 4 & & & & 6 & 10 \\
\hline Foreign language skills & H9 & 4 & & 2 & 1 & 3 & 10 \\
\hline Experience of export & $\mathrm{H} 10$ & & & 2 & 3 & 5 & 10 \\
\hline
\end{tabular}

Strong business capital has a positive impact on export activities in Cibaduyut, it is seen from the frequency data shows 8 respondents put the internal factor of this export in the number 5 which means very influential. The strong business capital is needed by SMEs for production and marketing. Moreover, in the case of production, SMEs must order raw materials demanded by customers to ensure raw material stock. If the raw materials run out, there will be no production activities. Therefore, strong business capital is needed by SMEs. Thus, SMEs apply gradual payments or advances to customers or apply cash payments for export activities. (H1: Strong business capital, has a positive impact on export activities in Cibaduyut is accepted).

The expertise of the workforce or craftsmen is a major factor in business activities in both production and marketing lines. It is approved by SME respondents in this study, frequency data shows as much as 6/10 respondents strongly agree or put score 5, that the expertise of the workforce to support the export activities. This is in harmony with the condition of Cibaduyut, which is a cluster of footwear with thousands of skilled craftsmen or experts, which makes many overseas buyers or brokers produce and buy products in Cibaduyut to be sent abroad. (H2: Skilled workforce, has a positive impact on export activities in Cibaduyut is accepted).
Good product made with innovation has an influence on export activities in Cibaduyut. 5/10 respondents put the quality of products offered in score 5 or very influential. Indeed Cibaduyut products have long been famous for the good products that are made but for the problem of innovation still have many obstacles, based on information from respondents. Therefore, SMEs realize that the good product and innovation are the things that have an influence on export activities in Cibaduyut. (H3: Good product made, has a positive impact on export activities in Cibaduyut is accepted).

Cibaduyut is in a very strategic location in Bandung, Cibaduyut's big name makes it easy to access. Large road conditions and located in a very strategic area to make business activities in this cluster is so alive. Plus, business activities from upstream to downstream in the footwear sector or the like are centered in this location. Among the advantages, 4/10 respondents placed the location factor is very influential (score 5) on export activities in Cibaduyut, where the rest or $6 / 10$ are neutral (score 3) to this location factor. This is because, when heavy rains or during peak hours there is always a long traffic jam and sometimes cause flooding when the rain is falling heavily. This also hampers business activities in Cibaduyut. Nevertheless, Cibaduyut's big name and lively location by various business activities make the location factor has a positive influence on export business activities in Cibaduyut. (H4: Strategic location, has a positive impact on export activities in Cibaduyut is accepted).

$7 / 10$ respondents strongly agree (score 5) that internal factors of marketing have a positive influence on export activities in Cibaduyut. Moreover, the name of Cibaduyut which is already well known as a footwear shopping center in the city of Bandung; Supporting the marketing of the name Cibaduyut itself. Marketing activities must be done by SMEs to get into the international market; especially the international market has a different condition from the domestic market. (H5: Intensive marketing, has a positive impact on export activities in Cibaduyut is accepted).

Machine equipment owned to support production needs is very influential on business activities in Cibaduyut, one of them for export. 6/10 respondents stated that adequate machine tools contribute (score 5) to fulfilling the demand of production from customers, by giving effectiveness to the production. (H6: Adequate machine tools, has a positive impact on export activities in Cibaduyut is accepted).

Adequate warehouse has an influence on export activity. Products that are finished in production or ready to be shipped and sold should be placed in a safe room so that the product is neat and not damaged. This makes it easy to list products that are ordered or searched by customers. Therefore, 6/10 respondents stated that the internal factor of adequate warehouse is a very influential (score 5) factor and has a positive impact on export business activities in Cibaduyut. (H7: Adequate warehouse, has a positive impact on export activities in Cibaduyut is accepted). 
From the results of frequency data, 6/10 respondents stated that the interesting packaging has a very high effect on export activities in Cibaduyut (score 5), but $4 / 10$ respondents stated that the interesting packaging has no effect (score 1) on export activity In Cibaduyut. Based on the description of the respondents, overseas buyers who come and shop for products in Cibaduyut not too concerned with attractive packaging, they usually will repackage Cibaduyut product more attractive. So it can reduce costs in purchasing products or product production in Cibaduyut. Nevertheless, from this result the researcher assumes that the attractive packaging has a positive effect on export activity in Cibaduyut. (H8: Attractive packaging, has a positive impact on export activities in Cibaduyut is accepted).

Talking about export business activities certainly cannot be separated from the language factor. From the frequency data in this study can be seen that $4 / 10$ respondents stated that the language factor is very no effect (score 1) on export business activities in Cibaduyut. 2/10 respondents are neutral towards this factor. Although SMEs do not have the ability to speak foreign languages or English well, they can still communicate through body language or Indonesian language or with translators brought by overseas buyers. From this data, the researcher assumed that foreign language ability factor had no effect to business activity in Cibaduyut. (H9: Foreign language skills, has a positive impact on export activities in Cibaduyut is rejected).

Experience in export activities perceived by SMEs, have a positive impact on business activities in Cibaduyut. Direct experience is felt to provide insight into export activities and new experiences for SMEs to explore the international market. This is consistent with the frequency data obtained, 5/10 respondents stated that experience in export activities has a high influence (score 5) on export activities, where $3 / 10$ respondents also stated this factor has an effect (score 4) on export activities in Cibaduyut. Researchers assume that experience of export activities have a positive impact on export activities in Cibaduyut. (H10: Experience of export, has a positive impact on export activities in Cibaduyut is accepted).

\section{Conclusion and Recommendation}

\subsection{Conclusion}

From the frequency data studied, 10 internal factors that include, strong business capital, skilled workforce, good product made, strategic location, intensive marketing, adequate machine tools, adequate warehouse, attractive packaging, foreign language skills, and availability of raw materials, studied to 10 respondents by using the data frequency approach of the development hypothesis, indicates that only the language factor is rejected in the hypothesis testing. In fact, the factor of foreign language ability is an important factor for SMEs to be able to conduct export business activities or find out about export opportunities independently. Internal factor is a very vital factor for SMEs to export; internal factors are factors that come from the condition of the company. These internal factors create a powerful motivational drive for exports from within the company or SME. As mentioned in the literature, SMEs have an important role to the economic growth of a country in general, and in particular SMEs can or have the potential to export and develop their line of business internationally. From this study, shows that, SMEs in Cibaduyut have been very aware of internal factors or conditions of the company to conduct or participate in international activities. However, the internal factors studied can be a constraint factor faced by SMEs because they cannot meet the expectations of foreign ldemand caused by one of the internal factors that are not met. SMEs in Cibaduyut can solve the internal factor problems for export by way of their own negotiations, although they are constrained in foreign language abilities.

\subsection{Recommendation}

Although the internal factor of foreign language proficiency is rejected in the testing hypothesis, it is helpful that a continuous foreign language training program is held in this cluster. In addition to SMEs in Cibaduyut cluster reliable in making products, it is expected they are also reliable in communicating foreign languages that will open more export opportunities. Knowledge and training on exports is also important to SMEs in Cibaduyut to understand how international market conditions are happening today, how to respond to dynamic changes in international markets, and how to provide added value that can increase the selling value of products made in this cluster. The location conditions in the Cibaduyut cluster need to be addressed in terms of road construction in order to provide comfort for domestic and foreign tourists, especially during peak hours.

\section{References}

1. L. Su, J Adams, Export capacity impact factors on Chinese SMEs: A survey analysis of Fujian Province. Journal of Chinese Economic and Foreign Trade Studies, 3(1), 57. (2010)

2. Y. Amornkitvikai, C Harvie, \& T. Charoenrat, Factors Affecting The Export Participation And Performance Of Thai Manufacturing Small And Medium Sized Enterprises (Smes). ICSB World Conference Proceedings (hal. 10). Washington: International Council for Small Business (ICSB). (2013)

3. M. Dressler, Managing export success - An empirical picture of German wineries' performance. BIO Web of Conferences, 2. (2015) 
4. J. Freeman, C. Styles, \& M. Lawley, Does firm location make a difference to the export performance of SMEs? International Marketing Review, 29(1), 90. (2012)

5. N.A. Morgan, C.S. Katsikeas, \& D.W. Vorhies, Export marketing strategy implementation, export marketing capabilities, and export venture performance. Academy of Marketing Science. Journal, 40(2), 272. (2012).

6. J. Asasongtham, S. Wichadee, The roles of foreign language in export operations of thai smes. International Journal of Entrepreneurship, 43. (2014).

7. D.K. Mutalemwa, Does globalisation impact SME development in Africa? African Journal of Economic and Management Studies, 6(2), 168. (2015).
8. F. Hashim, SMEs' impediments and developments in the internationalization process: Malaysian experiences. World Journal of Entrepreneurship, Management and Sustainable Development, 11(2), 101. (2015).

9. N.Z. Kovacevic, J.V. Tankosic, \& B. Lazic, The Mechanism Of Smes Internationalization Towards The Eu Single Market Perspective. Conference Proceedings of the International Scientific Conference (hal. 44-45). Pula: Sveuciliste Jurja Dobrile u Puli, Odjel za Ekonomiju i Turizam "Dr. Mijo Mirkovic". (2015).

10. T. Husain, Spatial Composition of Indian Small and Medium Enterprises' Export. Journal of International Economics, 7(2), 71, (2016). 